\title{
The Employment Time Bomb
}

Clark Kerr, chairman of the Carnegie Commission on Higher Education, recently warned that higher education was "sitting on a very real time bomb." In order to achieve the parity in faculty appointments by 1980 which the federal goverrment currently demands, America's 2,800 campuses will have to impose an immediate moratorium on the employment of the majority group. Dr. Kerr noted that "that's a very real time bomb." He further asked: "What happens to all of those who are now working on their PhD's and all of those below them who had planned to do so?"

Library schools are manufacturing a mini-version of the same employment time bomb. Last year over 5,000 library school graduates entered a labor market which is already approaching a supersaturated state.

How do we stem the flow of new graduates? One frequently-heard solution is to reduce the number of accredited library schools. But that is not practical unless there are schools willing to close their doors voluntarily. Accreditation is based solely on whether a school meets the published professional educational standards. In truth, there is no existing mechanism to control the number of graduating librarians. As a matter of fact, a recently-adopted ALA standard will make it very difficult for a school to monitor the quality of new library school students, without exposing itself to a charge of discrimination in one form or another.

Library administrators unintentionally have further reduced the job opportunities for new professionals. In an effort to stretch funds, or under the pressure of an increasingly perceptive and militant nonprofessional employment force, they are reassigning work to train nonprofessionals for work formerly performed by professionals.

What responsibilities does a professional school bear for the employment of its graduates? Should students be admitted to graduate school when the prospects for their employment are bleak? Surely some professional soul-searching is in order.

Many still argue that if libraries provided the full range of services recommended in the professional standards, we would be confronted with a shortage instead of a surplus of librarians. But the hard truth is that college and university libraries are now operating during a time when the prospects for significant budgetary growth do not appear bright; student enrollments have stabilized, and in some institutions have actually declined; the job market for many $\mathrm{PhD}$ 's is grim; 
at some institutions some departments are scrambling to justify the very existence of their programs. In short there is a wide chasm between professional aspirations and current budgetary reality.

American librarianship is indeed perched upon an employment time bomb. It can be defused only if our professional association and/or the library schools succeed in stemming the flow of new graduates. I can offer no instant solution, but I would strongly urge the suppliers (library schools) to communicate with their market (libraries) in order the better to assess the realities of the job situation. In the meantime, as competition for the available jobs intensifies, the manpower surplus will all too soon become a depressant upon salaries.

R. M. Dougherty 